\title{
Jornalismo, saúde e cidadania
}

Bernardo Kucinski ${ }^{1}$

Mudanças epidemiológicas e demográficas, assim como nas relações de gênero, na relação homem-natureza e no conceito saúde-doença, fizeram, de ações comunicativas, coadjuvantes principais de intervenções médicosanitárias tanto na esfera pública, como na privada. As transformações sociais das últimas décadas recolocaram a saúde no centro das lutas por direitos de cidadania, como já acontecera na época da revolução industrial. Nossa percepção da democracia mudou profundamente. Hoje se entende democracia como dada, e como uma conquista importante que se incorporou às sociedades humanas, especialmente por proclamar a igualdade política como legítima, justa e desejável. Mas também entendemos que, ao se instituir como sistema, a democracia manteve desigualdades sociais e deixou todo um elenco de promessas não cumpridas. A desigualdade crescente nas condições de saúde entre ricos e pobres, a começar pela própria diferença de expectativas de vida, é um dos mais pungentes testemunhos das promessas não cumpridas da democracia. Nos países periféricos, três entre quatro pessoas ainda morrem antes de completar cinquenta anos (WHO, 1998).

A democracia tornou-se o ambiente que legitima a luta pela redução da iniqüidade e alargamento de direitos de cidadania (Bobbio, 1990). E o direito de cidadania ganhou uma dimensão dinâmica, passando a ser definido como o "direito a ter direitos".

${ }^{1}$ Professor do Departamento de Jornalismo, Escola de Comunicações e Artes, Universidade de São Paulo, ECA-USP. 
Assim, na esfera da saúde e do meio ambiente, mais que em outras, ressurgiu o novo discurso organizador das demandas sociais, construído em torno do novo conceito de "cidadania", que aglutina grupos de pressão do campo popular em frentes de luta por novos direitos de cidadania no marco da democracia. Entre eles, o direito de todos a um meio ambiente saudável, o direito da mulher à saúde sexual e reprodutiva, o direito do hanseniano $e$ do epiléptico à auto-imagem, o direito do aidético à cura.

\section{Jornalismo e cidadania}

O jornalismo é uma atividade que, no conjunto das ações comunicativas da modernidade, tem sido historicamente um dos principais instrumentos de construção da democracia e de conquista de direitos de cidadania. Criou instituições e uma cultura de intervenção no quotidiano. Constitui uma relação social densa e demarcada, um modo específico de buscar e narrar a informação, um tipo de saber, uma práxis que inclui a construção da personalidade pública do jornalista e um ethos jornalístico.

Apesar de seu ofuscamento pelo entretenimento e propaganda nos meios de comunicação de massa, é cada vez mais ao jornalismo que cabem as tarefas de informar, combater o segredo de Estado, levantar polêmicas, denunciar abusos do poder, corrupção e violação dos direitos humanos. É como se tivesse um mandado da população para as funções de vigilância da cidadania e da justiça que o cidadão comum não consegue exercer mais diretamente.

Seus papéis de representação e mediação conferem ao jornalismo a ética que o distingue de outras ações comunicativas e que, apesar de algumas variações, conforme diferentes matrizes culturais e condições locais, tem como padrão referencial o jornalismo de qualidade das democracias pósindustriais. Nesse padrão, a busca da verdade é o valor ético transcendental. Não é considerada correta nenhuma ação jornalística que suprima a verdade. Trata-se de uma ética não conseqüencial, semelhante ao princípio transcendental de Kant, para a qual não importam as conseqüências da verdade.

A comunicação em saúde e meio ambiente tornou-se a matriz de um novo padrão de relações sociais entre agentes de saúde e cidadãos, baseada na interlocução, participação e co-responsabilidade nas decisões de saúde (Ratzan, 1997).

Em diversos países, inclusive no Brasil, pela Constituição cidadã de 1988, já se garante ao paciente o acesso pleno à informação sobre sua saúde, como um direito de cidadania de terceira geração, e o registro minucioso e preciso de todas as ações médicas.

Os tratados internacionais $e$ as constituições dos Estados modernos definem a saúde como um direito do cidadão. A Constituição da Organização Mundial de Saúde de 1946 proclamou a "obtenção do padrão de saúde mais alto possível um dos direitos fundamentais de todo ser humano, sem distinções econômicas e sociais". Trinta anos depois, a Organização Mundial de Saúde, OMS, atribuía a todos os governos a tarefa ambiciosa de "alcançar saúde para todos”, o que inspirou nossa Constituição cidadã de 1988, cujo 
artigo 196 diz: “ A saúde é um direito de todos e dever do Estado, garantido mediante políticas sociais e econômicas que visem à redução do risco à doença $e$ de outros agravos $e$ ao acesso universal $e$ igualitário às ações $e$ serviços para sua promoção, proteção e recuperação".

A concepção desse novo direito de cidadania ativa, no campo da saúde, confere à informação jornalística sobre saúde, sobre políticas públicas $e$ terapias de saúde, um valor político na esfera da cidadania, além de seus valores pedagógicos tradicionais em campanhas sanitárias e na medicina preventiva, ou de seu entendimento como "jornalismo de serviço". Por extensão, tornam-se objetos privilegiados de cobertura jornalística, vigilância e crítica, as políticas públicas de saúde dirigidas a grupos populacionais, como as campanhas de prevenção da aids ou de detecção do câncer da mama.

\section{O jornalismo e os novos conceitos de saúde}

O jornalista que hoje cobre problemas de saúde não pode mais se limitar às categorias definidas pela prática médica dominante. Deve poder dialogar com essa prática médica a partir de uma postura crítica. Ao jornalista, por sua ética, cabe uma visão holística do processo saúde-doença, e a consciência do relativismo da prática médica dominante. Para isso, necessita de conhecimento e noções de filosofia da ciência.

Os novos conceitos de saúde-doença têm vastas implicações na definição de políticas públicas de saúde

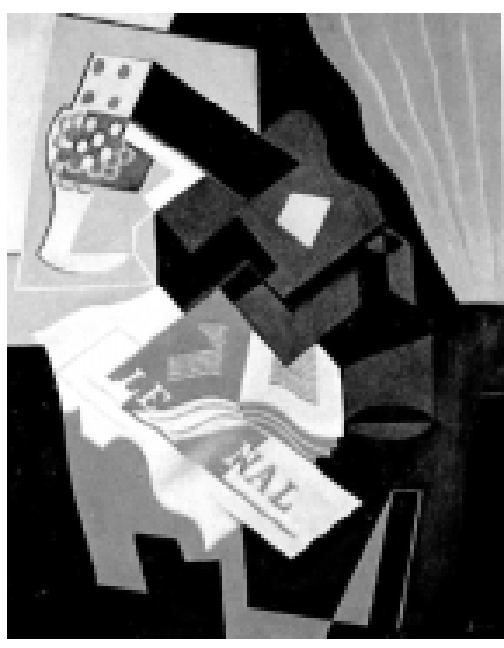

JUAN GRIS, Guitarra, livros e jornal, 1920. Instituto de Arte de Chicago. $e$, portanto, em seu acompanhamento jornalístico. Essas políticas não devem se limitar a combater focos ou endemias, ainda que isso continue sendo útil e necessário, mas devem procurar, principalmente, a melhoria da qualidade geral de vida da população. Mais do que causa, as endemias seriam a conseqüência da má qualidade ambiental ou de vida.

Melhorar moradia, transporte, saneamento, qualidade do ar e da alimentação seriam importantes políticas públicas a serem cobradas como essenciais ao exercício do direito à saúde.

Desde 1996, a Organização Panamericana de Saúde (OPAS) vem adotando, para marco referencial de suas campanhas, o conceito de desenvolvimento sustentado, como fundamento de uma qualidade de saúde satisfatória para todos. Por esse conceito, o desenvolvimento econômico deve ser direcionado à satisfação das necessidades básicas de toda a população e de forma a não comprometer a satisfação dessas mesmas necessidades nas gerações futuras.

Trata-se de uma proposta utópica no contexto latino-americano, mas assim têm sido outras estratégias, propostas e palavras de ordem lançadas sucessivamente pela OMS e pela OPAS, tais como a de "Saúde para todos no ano 2.000". Essas propostas têm o mérito de erigir conceitos como o direito à saúde ou desenvolvimento sustentado como desejáveis e justos. No 
entanto, o jornalista deve manter o distanciamento crítico e perceber o caráter utópico, e, em alguns casos, o caráter de fuga das campanhas públicas, quando tentam erradicar uma endemia sem alterar as condições sócio-econômicas, que são sua causa principal.

Na América Latina, inclusive no Brasil, que gasta apenas cerca de US\$ 200,00 por habitante/ano em saúde (OPAS, 1977) e onde ainda se lutam por direitos básicos de saúde, a proposta da "promoção da saúde" pode servir à legitimação do não cumprimento, pelo Estado, de suas responsabilidades como provedor de serviços e políticas de saúde. Mesmo assim, a proposta da "promoção da saúde" tem firme raiz no solo da cidadania. É uma decorrência direta da convivência mais longa dos idosos com suas famílias, da concepção holística dos problemas de saúde, não só de velhos, mas também de adolescentes, pela qual o ambiente e a convivência têm papel terapêutico, implicam que suas soluções não são meramente médico-terapêuticas, mas envolvem formas de relação social.

Um dos melhores exemplos é a reforma psiquiátrica italiana, hoje difundida em outros países, que devolveu os doentes mentais ao convívio da sociedade e de seus familiares, restaurando, ao mesmo tempo, seus direitos de cidadania, e pondo fim ao tratamento punitivo $e$ isolacionista do doente mental. Como restaurar esses laços, se seus familiares, suas comunidades, não os receberem $e$ não se envolverem ativamente no seu tratamento? $E$ se não forem aceitos?

No caso dos doentes mentais, a mídia tem uma responsabilidade muito especial, pois passou décadas reforçando estereótipos que agora precisam ser desconstruídos, caso contrário essas pessoas não serão aceitas pelas comunidades e familiares. Por exemplo, o estereótipo do doente mental como portador de níveis de agressividade crescente, tão repetido pela mídia, especialmente pela mídia de entretenimento, reflete um preconceito, não uma verdade científica (Philo, 1996).

Um outro exemplo é a pandemia da Aids, que se destacou entre cerca de vinte outras novas enfermidades surgidas no final do século não só pelo seu alcance, como por sua relação com fundamentos do comportamento humano e de nossa psique, dos direitos à liberdade sexual e à identidade de minorias sexuais, de conquista tão recente. Fracassaram todas as campanhas de prevenção da Aids concebidas segundo os princípios

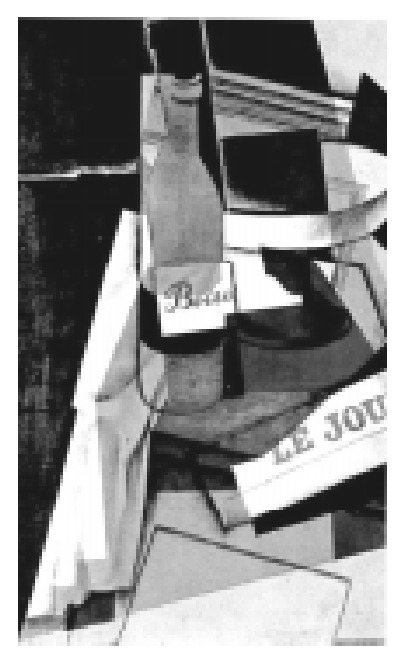
tradicionais do discurso e das técnicas de persuasão que visam mudar os hábitos das pessoas. Em 1997, dez anos depois de instalada a epidemia, ainda morriam por ano, 1.7 milhão de adultos (WHO, 1998).

Novos estereótipos foram criados e estereótipos antigos reforçados em abordagens que se revelaram equivocadas, centradas em "grupos de risco", inspiradas em visões moralistas ou religiosas do mundo, e não em conceitos epidemiológicos. Da estigmatização dos aidéticos surgiu todo um imaginário da doença, que deles subtraiu o direito básico ao tratamento integral e humano. Em torno da Aids, no entanto, organizou-se em todo o mundo uma enorme gama de movimentos populares e Organizações Não Governamentais 
(ONGs), que fizeram o nexo entre saúde e cidadania.

O fracasso da maioria das campanhas de prevenção da Aids dramatizou nossa falta de conhecimento ou nossos equívocos no entendimento da relação entre mensagem e receptor, no papel da interatividade, na capacidade de a informação mudar hábitos, idéias ou estilos de vida, no papel das linguagens na comunicação. Hoje se estuda com afinco as relações entre mensagem e linguagem, os discursos da comunicação, em busca de soluções mais eficazes. Ganharam ímpeto e urgência os estudos de comportamento e renasceu o interesse pela análise do conteúdo do discurso jornalístico.

O envolvimento do jornalista em campanhas de prevenção é delicado; pode levar à intimidade com instituições e agências de governo, à renúncia do distanciamento crítico e da capacidade de revelar e criticar políticas públicas; a trocar a lógica analítica e explicativa do bom jornalismo pela retórica da persuasão. Esse é um dos dilemas do jornalismo dedicado à saúde: como participar de campanhas sanitárias ou preventivas, de propaganda e de esclarecimento, sem violar a demarcação ética que distingue jornalismo de outras atividades comunicativas, em especial da propaganda e das relações públicas?

Se é óbvio o papel da comunicação e da propaganda nas campanhas preventivas, menos óbvio é o potencial de contradição e até mesmo antagonismo entre a ética jornalística e a ética referencial das ações do poder público. Suas ações apresentadas como as únicas possíveis, não são neutras; envolvem opções. O Estado decide dentro de um contexto de forças políticas e sob uma forte determinação de classe ou de estamentos, ou de interesses mercantis ou geo-políticos. No limite, campanhas de vacinação contra o sarampo e contra a tuberculose podem ser vistas não como a melhor forma de evitar essas doenças, mas como a melhor forma de não precisar mexer na estrutura econômica e social produtora do sarampo e da tuberculose, de não precisar prover emprego para todos, de perpetuar uma sociedade desigual e um habitat sujo. A prática médico-sanitária tem também uma dimensão de controle social (Berlinguer, 1978).

O conteúdo das mensagens, em geral sobre-determinado pelos códigos $e$ linguagens da propaganda convencional, também é um problema. Tanto por ser criado pelas agências de propaganda, como pela natureza dos veículos usados. Além de graves disfunções em público-alvo e em eficácia da mensagem, como se verificou nas primeiras campanhas de prevenção da Aids no Brasil, dá-se uma reiteração da ideologia dominante, seja diretamente, ou subliminarmente.

Por outro lado, as novas técnicas de manipulação do código genético, dos transplantes de órgãos e da reprodução fora do útero, têm vastas implicações nas esferas da cidadania e da ética. São de grande interesse jornalístico, independente de seu interesse médico. Sua cobertura é um grande desafio jornalístico. Exigem-se conhecimentos mais sofisticados da ciência, da genética e da medicina. Ao mesmo tempo, trazem dilemas éticos, como o acompanhamento da bioética, ainda em processo de construção nas comissões éticas organizadas nos hospitais para tratar dessas novas questões. 
Nem os tradicionais princípios da máxima beneficência e mínima maleficência, aplicados na determinação da justeza de experiência em seres vivos, e nem os conceitos usuais de direito civil parecem suficientes para responder a essas novas situações. Frente à complexidade dessas questões, cabe ao jornalista o papel delicado de socializar as discussões e contribuir para o processo de construção de uma nova moral.

\section{Referências bibliográficas}

BERLINGUER, G. Medicina e poder. São Paulo: Cebes/Hucitec, 1978.

BOBBIO, N. Estado, governo e sociedade. São Paulo: Paz e Terra,1990.

ORGANIZACIÓN PANAMERICANA DE LASALUD. Tercera evaluación de la aplicación de las

estrategias de salud pra todos en el año 2000: región de las Americas. Bol. Epidemiol., v.18, p.1-

$16,1997$.

PHILO, G. Media and mental distress. London: Longman, 1996.

RATZAN, S. C. Health Communication as negotiation. Am. Behav. Sci., v.38, p.224-7, 1997.

TURSHEN, M. The politics of public health. London: Zed Books, 1989.

WHO. World Health Report, 1998.Geneva: WHO, 1998.

PALAVRAS-CHAVE: jornalismo; saúde; direitos humanos.

KEY WORDS: journalism; health; human rights.

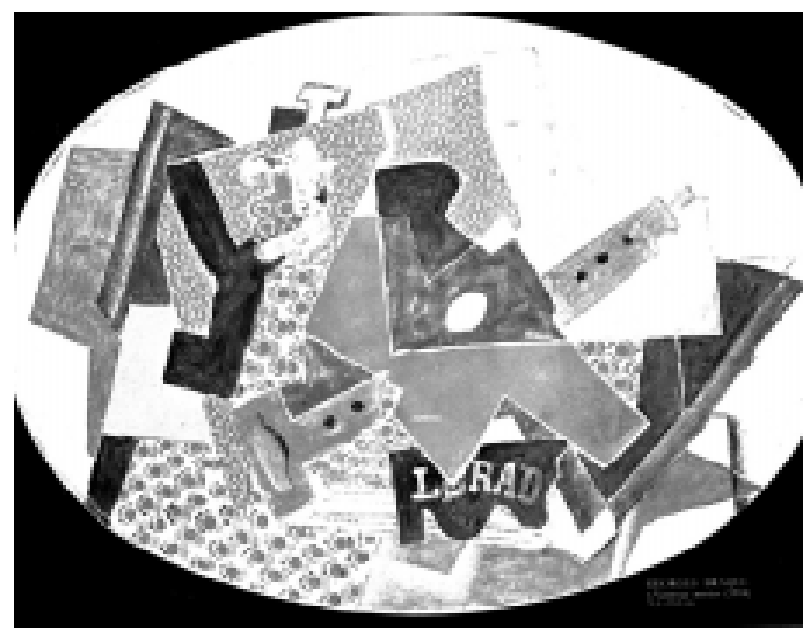

186 Interface - Comunic, Saúde, Educ 6 